\title{
Pacienții cu diabet zaharat la risc în pandemia COVID-19
}

\author{
Réka Toth ${ }^{1}$, Mihaela Chinceșan², Ovidiu Grama³, Alina Grama ${ }^{2}$ \\ ${ }^{1}$ Serviciul de management al calităţii serviciilor medicale, \\ Spitalul Clinic Judeţean de Urgenţă, Tg. Mureș, România \\ ${ }^{2}$ Clinica Pediatrie I, Spitalul Clinic Judeţean de Urgenţă Tg. Mureș, România \\ ${ }^{3}$ Clinica Obstetrică-Ginecologie II, Spital Clinic Judeţean Mureș, Tg. Mureș, România
}

\begin{abstract}
REZUMAT
Infecţia cu noul coronavirus (COVID-19) s-a răspândit rapid din focarul Wuhan, China având un spectru larg de manifestări clinice, de la cazuri asimptomatice până la cele fatale. Indivizii din categoria cu factori de risc, printre care și cei cu diabet zaharat (DZ), au un risc demonstrat mai mare de a dezvolta o formă de boală severă, precum și un risc mai mare de mortalitate. Prin acest articol ne-am propus să revizuim pe scurt caracteristicile generale ale COVID-19 și o situaţie specială, cea de infecţie la pacienţi cu DZ. Am abordat mecanismele potenţiale care pot crește susceptibilitatea pacienţilor diabetici pentru COVID-19, dar și recomandările actuale din România pentru diabetici în pandemia COVID-19. Pe baza dovezilor actuale, limitate, nu putem deduce concluzii, cercetări ulterioare cu privire la această asociere între COVID-19 și DZ sunt necesare și justificate.
\end{abstract}

Cuvinte cheie: SARS-CoV-2, infecţie, COVID-19, pandemie, comorbiditate, diabet zaharat

\section{INTRODUCERE}

În luna decembrie 2019, un nou coronavirus, numit acum sindrom respirator acut sever coronavirus 2 (SARS-CoV-2), a fost identificat ca fiind factorul etiologic al unui focar de boli respiratorii acute în $\mathrm{Wu}$ han, oraș din provincia Hubei, China. În luna februarie 2020, Organizaţia Mondială a Sănătăţii (OMS) a desemnat boala COVID-19. Infecţia s-a extins, ceea ce a determinat OMS să declare o urgenţă de sănătate publică în data de 30 ianuarie 2020 și să o caracterizeze drept pandemie în 11 martie 2020. La data de 5 mai 2020, erau 3.517.345 cazuri confirmate raportate oficial din peste 210 de ţări, cu 243.401 decese (1-2).

Scopul acestei lucrări este de a oferi o trecere în revistă a caracteristicilor generale ale COVID-19, precum o descriere a asocierii între această nouă boală infecţioasă şi diabetul zaharat.

\section{METODĂ}

A fost efectuată o revizuire a literaturii prin căutarea de articole de specialitate în limba engleză indexate în baze de date PubMed şi Google Scholar până în data de 4 mai 2020. Au fost utilizate următoarele cuvinte cheie: „SARS-CoV-2”, „COVID-19”, ,infecţie”, „,caracteristici clinice”, “comorbiditate”, „diabet zaharat", "prognoză”. Am accesat recomandările și articolele știinţifice disponibile în prezent pe site-ul OMS-ului, al Centrului European și al Statelor Unite pentru Controlul și Prevenirea Bolilor (ECDC, re- 
spectiv CDC), precum și pe site-ul Institutului Naţional de Sănătate Publică din România.

\section{CARACTERISTICI GENERALE COVID-19}

Etiologie. Coronavirusul care provoacă COVID-19 este un betacoronavirus din același subgenus cu virusul sindromului respirator acut sever (SARS), precum şi mai multe coronavirusuri de lilieci, dar într-o clasă distinctă. Structura regiunii genice care leagă receptorul este foarte similară cu cea a coronavirusului SARS și s-a dovedit că virusul utilizează același receptor, enzima de conversie a angiotensinei 2 (ACE2), pentru intrarea în celule (3). "Coronavirus Study Group" pentru taxonomia virușilor a propus ca acest virus să fie desemnat SARS-CoV-2 (4).

Epidemiologie - distribuţie, calea de transmitere. Sunt raportate cazuri pe toate continentele, cu excepţia Antarcticii, și sunt în creștere constantă în întreaga lume. Clustere de transmitere locală crescută pot fi găsite acum în Europa de Vest, Statele Unite și Iran. Incidenţa cumulativă variază în funcţie de ţară și, probabil, depinde de o serie de factori, precum demografia și densitatea populației, gradul de testare și raportare, strategiile de prevenire și combatere.

La începutul focarului, ancheta epidemiologică din Wuhan a identificat o asociere iniţială cu o piaţă de fructe de mare care vindea animale vii, unde majoritatea pacienţilor au lucrat sau au fost vizitatori (5). $\mathrm{Cu}$ toate acestea, pe măsură ce focarul a progresat, răspândirea de la persoană la persoană a devenit principalul mod de transmitere, însă modul exact nu este clar. Se consideră că transmiterea are loc prin picături respiratorii de la tuse și strănut, la fel ca și în cazul altor agenţi patogeni respiratori, inclusiv gripa şi rinovirusul (6). Virusul eliberat din secreţiile respiratorii ale unei persoane infectate pot infecta o altă persoană dacă face contact direct cu mucoasele; infecţia poate apărea, de asemenea, dacă o persoană atinge o suprafaţă infectată și apoi atinge ochii, nasul sau gura. De obicei, picăturile nu se transmit mai departe de aproximativ $2 \mathrm{~m}$ și nu persistă în aer. O problemă controversată reprezintă dacă SARS-CoV-2 poate fi transmis pe rută aeriană în condiţii naturale, însă relevanţa directă şi implicaţiile clinice ale acestor descoperiri nu sunt clare. Precauţiile aeriene sunt recomandate atunci când se efectuează proceduri generatoare de aerosoli (7-15). Durata vărsării virale variază semnificativ și posibil depinde de gravitate. SARS-CoV-2 poate fi transmis înainte de debutul simptomelor și pe parcursul bolii (16-19). Riscul de transmitere de la un individ cu infecţie SARS-CoV-2 variază în funcţie de tipul și durata expunerii, de utilizarea măsurilor preventive şi de factori individuali probabili (de exemplu, cantitatea de virus în secreţiile respiratorii). Cele mai multe infecţii secundare au fost descrise printre persoanele de contact din gospodărie, în unităţile de îngrijire sau de servicii medicale atunci când nu au fost utilizate echipamente de protecţie personală, și în spaţii închise (nave de croazieră). Adunările sociale sau de muncă sunt, de asemenea, risc de transmitere prin contact restrâns (20-23). Virusul prezent pe suprafețele contaminate poate fi o altă sursă de infecţie. Frecvenţa și importanţa relativă a acestui tip de transmisie rămân neclare, poate fi mai probabil o sursă potenţială de infecţie în anumite circumstanţe (de exemplu, în gospodăria unei persoane infectate sau în spitale) $(7,9,24-28)$.

Caracteristici clinice. Pacienţii cu COVID-19 au prezentat o gamă largă de forme clinice, de la asimptomatic/simptome ușoare până la boli grave și deces. Simptomele pot apărea la 2-14 zile după expunerea la virus și sunt următoarele: tuse, dispnee sau insuficienţă respiratorie, febră, frisoane, dureri musculare, durere de gât, pierdere nouă de gust sau miros. Au fost raportate alte simptome mai puţin frecvente, ca simptome gastro-intestinale (greaţă, vărsături sau diaree) (29). Copiii au simptome similare cu adulţii și au, în general, manifestări ușoare, deși au fost raportate cazuri de copii cu COVID-19 forme severe și 2 decese (30-34). Boala severă apare predominant la adulţi cu vârstă înaintată sau cu comorbidităţi medicale subiacente.

O analiză bazată pe date din China și în afara acesteia arată că vârsta este un gradient puternic în riscul de deces. La fel, rata de spitalizare a crescut odată cu vârsta, cu o rată de 1\% pentru cei 20-29 ani, de 4\% pentru cei 50-59 de ani și $18 \%$ pentru $>80$ de ani (35). Vârsta mai înaintată este asociată și cu mortalitatea crescută. Au fost raportate din Italia rate de fatalitate a cazurilor de la 12,8 până la $20,2 \%$ în rândul celor cu vârsta cuprinsă între 70 şi 79 de ani şi, respectiv, $\geq 80$ de ani $(36,37)$.

Factorii de risc epidemiologici stabiliţi sunt: vârsta $>65$ ani, boala pulmonară preexistentă, boala renală cronică, DZ, istoric de hipertensiune arterială, istoric al bolilor cardiovasculare (BCV), obezitate (IMC $\geq$ 30), iar cei posibili includ: utilizarea de substanţe bio- 
logice (ex. inhibitori de TNF, inhibitori de interleukină, agenţi anticelule B), istoric de transplant sau alte stări de imunosupresie și HIV, număr de celule CD4 < 200 celule/ $\mu 1$ sau număr necunoscut de CD4. CDC include, de asemenea, și boli hepatice ca factori de risc potenţiali pentru boala severă $(20,38)$. Sexul masculin a constituit un număr mai mare de decese în cohortele din China, Italia și Statele Unite (36,39-40). Prognosticul slab a fost asociat și cu unele caracteristici particulare de laborator, cum sunt: limfopenia, enzime hepatice crescute, LDH crescut, reactanţi de fază acută crescute (ex. proteină C reactivă, feritină), D-dimer ridicat $(>1 \mathrm{mcg} / \mathrm{ml})$, timp crescut de protrombină, troponină crescută, creatinfosfokinază ridicată, leziuni renale acute (20).

Diagnosticul infectiei COVID-19. Testarea pacienţilor, care îndeplinesc criteriile stabilite de OMS și cele guvernamentale, se poate efectua în laboratoarele de sănătate publică de stat, spitale şi unele laboratoare comerciale. Reacţia în lanț a polimerazei în transcripţie inversă (RT-PCR) pentru virusul COVID-19 este metoda standard pentru a diagnostica iniţial virusul din probe respiratorii (tampoane orofaringiene și nazofaringiene) și probe de tract respirator inferior (spută), la pacienţii cu tuse productivă (41).

SARS-CoV-2 invadează tractul respirator și plămânii, ceea ce duce la un nou tip de pneumonie virală (42), în care cazurile severe pot progresa rapid în sindrom de detresă respiratorie, șoc septic și sindrom de disfuncţii multiple de organe (43). Managementul cazurilor și măsurile preventive nu sunt abordate în acest articol. Indivizii din categoria cu factori de risc, menţionaţi mai sus, au un risc demonstrat mai mare de a dezvolta o formă de boală severă, precum și un risc mai mare de mortalitate $(16,44-45)$.

În continuare vom rezuma o situaţie specială, aceea de infecţie SARS-CoV-2 la pacienţii cu DZ, impactul între cele două pandemii globale fiind o realitate sumbră a faptului că $\mathrm{DZ}$ este a doua cea mai frecventă comorbiditate în boala COVID-19 (16).

\section{ASOCIERE ÎNTRE COVID-19 ŞI DZ}

Ratele diabetului la pacienţii infectaţi cu SARS$\mathrm{CoV}$-2. Ratele diabetului zaharat de tip 2 (T2D) la pacienţii cu COVID-19 variază în funcţie de vârstă, populaţie studiată, gravitatea bolii şi metoda de testare. Într-o raportare din China, diabetul a fost prezent la aproximativ 15\% dintre 1.099 pacienţi (copii și adulţi) internaţi cu diagnostic confirmat în laborator (43). Analiza unui subset ales aleatoriu de cazuri fatale de COVID-19 în Italia (vârsta medie 79,5 ani) a relevat o prevalenţă a diabetului de 35\% (36). Într-o raportare din 3 aprilie 2020 din Statele Unite, cu 7.162 de cazuri confirmate de COVID-19 (între 12 februarie şi 28 martie 2020) și catalogate de CDC examinând comorbidităţile, pe primul loc ca frecvenţă s-a situat diabetul $(10,9 \%)$, dintre care $6 \%$ nespitalizat, $24 \%$ spitalizat în secţii de nonterapie intensivă, respectiv 32\% spitalizate în terapie intensivă (49). În România, în data de 5 mai 2020, dintre cele 803 de decese, 243 $(30,3 \%)$ prezentau diabetul ca fiind comorbiditate. Menţionăm că prevalenţa DZ în România conform studiului PREDATORR este de 11,6\% (50).

Susceptibilitate la infecţii în rândul pacienţilor cu $D Z$. Este acceptată pe scară largă atât în medicină, cât și de publicul larg că diabeticii au o tendinţă crescută de a dezvolta infecţii. Deși mai multe studii epidemiologice au arătat că diabeticii primesc mai des tratament pentru infecţii decât nondiabeticii (46), amploarea efectului diabetului asupra riscului de infecţie rămâne o întrebare activă de cercetare. Un studiu din Olanda a evaluat numărul de infecţii la pacienţi cu DZ tip 2 îngrijiţi într-un cabinet de medicină generală pe o perioadă de 2 ani. 458 de infecţii au fost prezente la 193 de pacienţi, având o medie de $2,4( \pm 1,9)$ infecţii la fiecare pacient (47). Torres şi colab. rezumă în studiul lor că pacienţii cu diabet prezintă un risc crescut de până la 1,4 (OR) pentru pneumonie comunitară. Riscul de spitalizare legată de pneumonie asociat diabetului a fost, de asemenea, mai mare la cei care nu au alte comorbidităţi și la cei cu o durată mai lungă de diabet și/sau un control glicemic slab (bazat pe niveluri de hemoglobină A1C) (48). Majoritatea, dar nu toate studiile, sugerează că riscul de infecţie în DZ este asociat cu hiperglicemie sau lipsa controlului diabetului zaharat; de exemplu, Critchley şi colab. demonstrează asocierea puternică, însă raportul din Olanda menţionat mai sus, cu limitele studiului, concluzionează că hiperglicemia este mai probabil un rezultat decât o cauză a infecţiilor comune $(47,49)$.

Mecanisme potenţiale care pot crește susceptibilitatea pacienţilor cu DZ pentru COVID-19 includ: 1) legarea celulară cu afinitate mai mare și intrarea eficientă a virusului, 2) scăderea clearance-ului viral, 3) diminuarea funcţiei celulelor $T, 4)$ sensibilitate crescută la hiperinflamare și sindrom de ,furtună de citokine“ și 5) prezenţa BCV (51). 
SARS-CoV-2 folosește receptorii ACE2 pentru intrarea în celulele ţintă și o expresie sporită a ACE2 a fost demonstrată în plămâni, rinichi, inimă și pancreas în modele de rozătoare cu DZ (3,52-53). Administrarea insulinei atenuează expresia ACE2, în timp ce agenţii hipoglicemici (de exemplu, glucagon-like peptide-1 receptor agonist, tiazolidinediones), inhibitorii ACE și statinele reglează ACE2 (51). Rao și colab. au explorat boli sau trăsături care pot fi legate cauzal de creșterea expresiei ACE2 în plămân. Au descoperit că DZ a fost asociat cauzal cu expresia crescută de ACE2 pulmonară (54). De altfel, și nivelurile circulante ale furinei (protează celulară care implică intrarea virală) sunt crescute la pacienţii cu DZ (55).

Analizând date demografice, clinice și de laborator de la 106 de pacienţi spitalizaţi într-un spital din Wuhan, între 5 ianuarie şi 25 februarie 2020, căutând factori care influenţează negativ clearance-ul SARSCoV-2, Chen şi colab. au constatat că vârsta înaintată, sexul masculin și factori asociaţi cu ACE2 (inclusiv hipertensiune arterială, DZ și BCV) au afectat negativ clearance-ul viral (56).

Oamenii și șoarecii cu DZ tip 2 prezintă o schimbare a macrofagelor, predominant reglatorii sau antiinflamatorii, și a celulelor $\mathrm{T}$ reglatoare din ţesutul adipos în macrofage predominant proinflamatorii și celule Th1 (T helper tip 1) și Th17 CD4 ${ }^{+}$T. Kulcsar și colab. au examinat efectele DZ într-un model de şoarece umanizat infectat cu MERS-CoV, aflat pe o dietă bogată în grăsimi. Boala a fost mai severă și prelungită la șoareci diabetici și masculi și s-a caracterizat prin alterarea numărului de celule $\mathrm{CD}^{+} \mathrm{T}$ și răspunsuri anormale de citokine (valori crescute IL17a). Se crede că acest profil imun alterat contribuie la varietate de consecinţe asociate cu DZ tip 2, inclusiv o susceptibilitate crescută la infecţii (57). Studii epidemiologice indică faptul că DZ tip 2 a fost comorbiditatea principală asociată cu infecţii MERS-CoV severe sau letale (58). În ceea ce privește actuala pandemie COVID-19, DZ este a doua cea mai frecventă comorbiditate (16).

Nivelurile plasmatice ale biomarkerilor inflamatori (interleukina-6, feritina serică, proteina $C$ reactivă) și ale D-dimerului sunt mai crescute la pacienţii cu COVID-19 și DZ comparativ la cei fără, sugerând că diabeticii sunt mai susceptibili la ,furtuna de citokine“, ceea ce duce la deteriorarea rapidă a bolii (59).

Având în vedere prevalenţa crescută a BCV, obezităţii și hipertensiunii la pacienţii diabetici, nu se știe dacă DZ contribuie în mod independent la acest risc crescut de boală severă a infecţiei cu SARS-CoV-2. În orice caz, nivelurile de glucoză plasmatică și DZ sunt predictori independenţi pentru mortalitate şi morbiditate la pacienţii cu SARS (60).

Provocări pentru clinicieni şi diabetici. Având în vedere situaţia actuală, lipsa unor dovezi știinţifice solide și lipsa de tratament specific, COVID-19 a devenit o problemă de sănătate la nivel mondial. În prezent, carantina, izolarea, distanţarea socială și restricţiile stricte asupra călătoriilor interne și internaţionale sunt cele mai eficiente strategii preventive, împreună cu practicarea unei bune igiene. Aceste măsuri, probabil, au impact în agravarea controlului glucozei: limitarea activităţii fizice a persoanelor cu DZ; restricţionarea livrărilor de alimente în timpul carantinei ar fi obligat diabeticii să-şi modifice obiceiurile alimentare care au fost mai devreme asociate cu un control bun al glicemiei; achiziţionarea de medicamente antidiabetice şi benzile de testare a valorilor glucozei ar fi fost dificile pe fondul restricţiilor; nu ar fi putut să-şi viziteze medicii pentru urmărirea de rutină a stării (61). Pentru astfel de situaţii, sunt foarte importante educaţia și susţinerea autogestionării diabetului. Clinicienii, de asemenea, trebuie să fie proactivi pentru a răspunde nevoilor pacienţilor care utilizează telemedicina, inclusiv apeluri telefonice sau video, dacă sunt disponibile. Este posibil ca reglementarea îngrijirii prin aceste mijloace de tehnologii avansate să aibă un impact de durată asupra modului în care diabeticii sunt trataţi și urmăriţi pe termen lung (62).

Recomandările specifice pentru persoanele cu DZ oferite de Federaţia Română de Diabet, Nutriţie și Boli Metabolice sunt după cum urmează: reducerea numărului de persoane cu care se intră în contact; evitarea contactului cu persoanele suspecte de infecţii respiratorii acute; reducerea deplasărilor; curăţarea suprafeţelor cu risc cu dezinfectanţi pe bază de clor sau alcool; măsuri de igienă individuală, cu evitarea atingerii feţei, ochiilor, nasului și gurii; spălarea foarte frecventă pe mâini cu apă și săpun (minimum 20 secunde) şi neapărat înaintea utilizării glucometrului şi a injectării de insulină sau a altei medicaţii injectabile; utilizarea măștilor de protecţie; fără consum de medicamente antivirale și antibiotice, decât în cazul în care le prescrie medicul; menţinerea legăturii cu specialistul diabetolog și cu medicul de familie pentru planificarea vizitei/ prescrierii reţetei şi stabilirea metodei prin care diabeticii ajung în posesia reţetei/me- 
dicaţiei; asigurarea medicaţiei suficiente, inclusiv medicaţia comorbidităţilor (3 luni) şi suficiente teste de monitorizare ale glicemiei pentru a nu exista întreruperi în administrare; când sunt probleme în aprovizionarea farmaciilor cu medicaţia antidiabetică, contactarea diabetologului în înlocuirea medicaţiei; control glicemic, prin respectarea recomandărilor de stil de viaţă și medicaţie; respectarea recomandărilor de dietă; 7-8 ore somn pe noapte; activitate fizică în casă; asigurarea că sunt posibile controlul și tratamentul hipoglicemiei (zahăr la îndemână); asigurarea necesarului în caz de autoizolare/carantină/îmbolnăvire; listă cu persoanele de contact și numerele de telefon (membri ai familiei, medicul de familie, medicul diabeto$\log$ ), tratamentul urmat și medicaţia pentru a fi disponibile în caz de urgenţă sau de îmbolnăvire (63).

\section{BIBLIOGRAFIE}

1. World Health Organization. Coronavirus disease (COVID-19) Pandemic 2020 [05/05/2020]. Available from: https://www.who.int/ emergencies/diseases/novel-coronavirus-2019/situation-reports/ (Accessed on 6 May 2020).

2. World Health Organization. Rolling updates on coronavirus disease (COVID-19) 2020 [05/05/2020]. Available from: https://www.who.int/ emergencies/diseases/novel-coronavirus-2019/events-as-they-happen.

3. Zhou P, Yang XL, Wang XG et al. A pneumonia outbreak associated with a new coronavirus of probable bat origin. Nature 2020;579:270.

4. Gorbalenya AE et al. Severe acute respiratory syndrome-related coronavirus - the species and its viruses, a statement of the Coronavirus Study Group. Preprint at https://www.biorxiv.org/content/ 10.1101/2020.02.07.937862v1 (2020).

5. World Health Organization. Novel coronavirus situation report-2. January 22, 2020. https://www.who.int/docs/default-source/ coronaviruse/situation-reports/20200122-sitrep-2-2019-ncov.pdf (Accessed on 6 May 2020).

6. CDC. 2019 Novel Coronavirus, Wuhan, China: Frequently Asked Questions and Answers. CDC. Available at https://www.cdc.gov/ coronavirus/2019-ncov/faq.html. January 27, 2020 (Accessed on 6 May 2020).

7. van Doremalen N, Bushmaker T, Morris DH et al. Aerosol and Surface Stability of SARS-CoV-2 as Compared with SARS-CoV-1. N Engl J Med. 2020;382:1564.

8. Guo ZD, Wang ZY, Zhang SF et al. Aerosol and Surface Distribution of Severe Acute Respiratory Syndrome Coronavirus 2 in Hospital Wards, Wuhan, China, 2020. Emerg Infect Dis. 2020;26.

9. Ong SWX, Tan YK, Chia PY et al. Air, Surface Environmental, and Personal Protective Equipment Contamination by Severe Acute Respiratory Syndrome Coronavirus 2 (SARS-CoV-2) From a Symptomatic Patient. JAMA. 2020.

10. Bahl P, Doolan C, de Silva C et al. Airborne or droplet precautions for health workers treating COVID-19? J Infect Dis. 2020.

11. Liu $Y$, Ning Z, Chen $Y$ et al. Aerodynamic analysis of SARS-CoV-2 in two Wuhan hospitals. Nature. 2020.

12. Wong SC, Kwong RT, Wu TC et al. Risk of nosocomial transmission of coronavirus disease 2019: An experience in a general ward setting in Hong Kong. J Hosp Infect. 2020.

13. Ng K, Poon BH, Kiat Puar TH et al. COVID-19 and the Risk to Health Care Workers: A Case Report. Ann Intern Med. 2020.

14. Bourouiba L. Turbulent Gas Clouds and Respiratory Pathogen Emissions: Potential Implications for Reducing Transmission of COVID-19. JAMA. 2020.

\section{CONCLUZII}

COVID-19 s-a răspândit rapid din focarul din Wuhan, China și are un spectru larg de manifestări clinice. Izolarea, diagnosticul și managementul precoce asociat aduc un control mai bun al bolii.

S-a demonstrat că, în calitate de comorbiditate, diabetul zaharat poate fi predictor al morbidităţii și mortalităţii.

Distanţarea socială, igiena strictă, self-managementul bun al diabetului și comunicarea cu medicul specialist diabetolog sunt foarte importante în pandemia COVID-19.

Conflict of interest: none declared Financial support: none declared

15. Lu J, Gu J, Li K et al. COVID-19 Outbreak Associated with Air Conditioning in Restaurant, Guangzhou, China, 2020. Emerg Infect Dis. 2020;26.

16. Zhou F, Yu T, Du R, Fan G, Liu Y, Liu Z et al. Clinical course and risk factors for mortality of adult inpatients with COVID-19 in Wuhan, China: A retrospective cohort study. Lancet. 2020.

17. Liu Y, Yan LM, Wan L, Xiang TX, Le A, Liu JM et al. Viral dynamics in mild and severe cases of COVID-19. Lancet Infect Dis. 2020.

18. Zheng S, Fan J, Yu F et al. Viral load dynamics and disease severity in patients infected with SARS-CoV-2 in Zhejiang province, China, January-March 2020: Retrospective cohort study. BMJ. 2020;369:m1443

19. Xu K, Chen Y, Yuan J et al. Factors associated with prolonged viral RNA shedding in patients with COVID-19. Clin Infect Dis. 2020.

20. Kenneth Mclntosh. Coronavirus disease 2019 (COVID-19): Epidemiology, virology, clinical features, diagnosis, and prevention. In: UpToDate, Post, TW (Ed), UpToDate, Waltham, MA, 2020.

21. McMichael TM, Clark S, Pogosjans S et al. COVID-19 in a LongTerm Care Facility - King County, Washington, February 27-March 9, 2020. MMWR Morb Mortal Wkly Rep 2020;69:339.

22. $\mathrm{Ng} \mathrm{D}, \mathrm{Hu} \mathrm{B}, \mathrm{Hu} \mathrm{C}$ et al. Clinical Characteristics of 138 Hospitalized Patients With 2019 Novel Coronavirus-Infected Pneumonia in Wuhan, China. JAMA. 2020.

23. Kakimoto K, Kamiya H, Yamagishi T et al. Initial Investigation of Transmission of COVID-19 Among Crew Members During Quarantine of a Cruise Ship - Yokohama, Japan, February 2020. MMWR Morb Mortal Wkly Rep. 2020; 69:312.

24. Yung CF, Kam KQ, Wong MSY et al. Environment and Personal Protective Equipment Tests for SARS-CoV-2 in the Isolation Room of an Infant With Infection. Ann Intern Med 2020.

25. Kampf G, Todt D, Pfaender S, Steinmann E. Persistence of coronaviruses on inanimate surfaces and their inactivation with biocidal agents. J Hosp Infect. 2020; 104:246.

26. Rabenau HF, Cinatl J, Morgenstern B et al. Stability and inactivation of SARS coronavirus. Med Microbiol Immunol. 2005; 194:1.

27. Otter JA, Donskey C, Yezli S et al. Transmission of SARS and MERS coronaviruses and influenza virus in healthcare settings: the possible role of dry surface contamination. J Hosp Infect. 2016; 92:235.

28. Wölfel R, Corman VM, Guggemos W et al. Virological assessment of hospitalized patients with COVID-2019. Nature. 2020.

29. CDC. 2019 Novel Coronavirus, Wuhan, China: Symptoms. CDC. Available at https://www.cdc.gov/coronavirus/2019-ncov/about/ symptoms.html. January 26, 2020; (Accessed on 6 May 2020).

30. Wu Z, McGoogan JM. Characteristics of and Important Lessons From the Coronavirus Disease 2019 (COVID-19) Outbreak in China: 
Summary of a Report of 72314 Cases From the Chinese Center for Disease Control and Prevention. JAMA. 2020 Feb 24.

31. Dong Y, Mo X, Hu Y, Qi X, Jiang F, Jiang Z et al. Epidemiological Characteristics of 2143 Pediatric Patients With 2019 Coronavirus Disease in China. Pediatrics. 2020.

32. Qiu H, Wu J, Hong L, Luo Y, Song Q, Chen D. Clinical and epidemiological features of 36 children with coronavirus disease 2019 (COVID-19) in Zhejiang, China: An observational cohort study. Lancet Infect Dis. 2020

33. Shelley Riphagen, Xabier Gomez, Carmen Gonzalez-Martinez et al. Hyperinflammatory shock in children during COVID-19 pandemic. Published online: May 06, 2020. Available at: https://www.thelancet. com/action/showPdf?pii=S0140-6736\%2820\%2931094-1 (Accessed on: 09 May 2020).

34. https://www.worldometers.info/coronavirus/ (Accessed on 9 May 2020).

35. Verity R, Okell LC, Dorigatti I et al. Estimates of the severity of coronavirus disease 2019: a model-based analysis. Lancet Infect Dis 2020.

36. Onder G, Rezza G, Brusaferro S. Case-Fatality Rate and Characteristics of Patients Dying in Relation to COVID-19 in Italy. JAMA. 2020.

37. Report of the WHO-China Joint Mission on Coronavirus Disease 2019 (COVID-19). Published February 16, 2020. Available at: https:// www.who.int/docs/default-source/coronaviruse/who-china-joint-mission-on-covid-19-final-report.pdf (Accessed on 9 May 2020).

38. Centers for Disease Control and Prevention. People who are at higher risk for severe illness https://www.cdc.gov/coronavirus/2019ncov/need-extra-precautions/people-at-higher-risk.html (Accessed on 9 May 2020).

39. Chen $\mathrm{T}, \mathrm{Wu} \mathrm{D}, \mathrm{Chen} \mathrm{H}$ et al. Clinical characteristics of 113 deceased patients with coronavirus disease 2019: retrospective study. BMJ 2020;368:m1091.

40. Richardson S, Hirsch JS, Narasimhan M et al. Presenting Characteristics, Comorbidities, and Outcomes Among 5700 Patients Hospitalized With COVID-19 in the New York City Area. JAMA. 2020.

41. World Health Organization. Coronavirus disease (COVID-19) technical guidance: Laboratory testing for 2019-nCoV in humans 2020. Available from: https://www.who.int/emergencies/diseases/ novel-coronavirus-2019/technicalguidance/laboratory-guidance (Accessed on 9 May 2020).

42. Zhu N, Zhang D, Wang W et al.; China Novel Coronavirus Investigating and Research Team. A novel coronavirus from patients with pneumonia in China, 2019. N Engl J Med. 2020;382:727-733.

43. Guan WJ, Ni ZY, Hu Y et al.; China Medical Treatment Expert Group for COVID-19. Clinical characteristics of coronavirus disease 2019 in China. N Engl J Med. 2020.

44. Wang D, Hu B, Hu C et al. Clinical characteristics of 138 hospitalized patients with 2019 novel coronavirus-infected pneumonia in Wuhan, China. JAMA. 2020.

45. Zhang $P, Z$ Zhu $L$, Cai $J$ et al. Association of inpatient use of angiotensin converting enzyme inhibitors and angiotensin II receptor blockers with mortality among patients with hypertension hospitalized with COVID-19. Circ. Res. 2020.

46. Mor A, Berencsi K, Nielsen JS et al. Rates of Community-based Antibiotic Prescriptions and Hospital-treated Infections in Individuals
With and Without Type 2 Diabetes: A Danish Nationwide Cohort Study, 2004-2012. Clin Infect Dis 2016;63:501.

47. Bartelink ML, Hoek L, Freriks JP, Rutten GE. Infections in patients with type 2 diabetes in general practice. Diabetes Res Clin Pract 1998;40:15.

48. Torres A, Blasi F, Dartois $\mathrm{N}$ et al. Which individuals are at increased risk of pneumococcal disease and why? Impact of COPD, asthma, smoking, diabetes, and/or chronic heart disease on communityacquired pneumonia and invasive pneumococcal disease. Thorax. 2015 Oct. 70 (10):984-9.

49. Team CC-R. Preliminary estimates of the prevalence of selected underlying health conditions among patients with coronavirus disease 2019 - United States, February 12-March 28, 2020. MMWR Morb Mortal Wkly Rep 2020;69:382-386.

50. Mota M, Popa SG, Mota E et al. Prevalence of diabetes mellitus and prediabetes in the adult Romanian population: PREDATORR study. $J$ Diabetes. 2016;8(3):336-44.

51. Muniyappa R, Gubbi S. COVID-19 Pandemic, Corona Viruses, and Diabetes Mellitus. Am J Physiol Endocrinol Metab. 2020.

52. Roca-Ho H, Riera M, Palau V et al. Characterization of ACE and ACE2 Expression within Different Organs of the NOD Mouse. Int $J$ Mol Sci. 2017;18:563.

53. Wysocki J, Ye M, Soler MJ et al. ACE and ACE2 activity in diabetic mice. Diabetes. 2006;55:2132-39.

54. Rao S, Lau A, So H-C. Exploring diseases/traits and blood proteins causally related to expression of ACE2, the putative receptor of 2019- nCov: A Mendelian randomization analysis (Preprint). medRxiv:2020.2003.2004.20031237.

55. Fernandez C, Rysä J, Almgren P et al. Plasma levels of the proprotein convertase furin and incidence of diabetes and mortality. $J$ Intern Med. 2018;284:377-87.

56. Chen X, Hu W, Ling J, Mo P et al. Hypertension and diabetes delay the viral clearance in COVID-19 patients (Preprint). medRxiv: 2020.2003.2022.20040774.

57. Kulcsar KA, Coleman CM, Beck SE, Frieman MB. Comorbid diabetes results in immune dysregulation and enhanced disease severity following MERS-CoV infection. JCl Insight. 2019;4(20):e131774.

58. Alqahtani FY, Aleanizy FS, Ali El Hadi Mohamed R et al. Prevalence of comorbidities in cases of Middle East respiratory syndrome coronavirus: A retrospective study [published online ahead of print, 2018 Nov 5]. Epidemiol Infect. 2018;147:1-5.

59. Guo W, Li M, Dong Y et al. Diabetes is a risk factor for the progression and prognosis of COVID-19 [published online ahead of print, 2020 Mar 31]. Diabetes Metab Res Rev. 2020;e3319.

60. Yang JK, Feng Y, Yuan MY et al. Plasma glucose levels and diabetes are independent predictors for mortality and morbidity in patients with SARS. Diabet Med. 2006;23:623-628.

61. Banerjee M, Chakraborty S, Pal R. Diabetes self-management amid COVID-19 pandemic. Diabetes Metab Syndr. 2020;14(4):351-354.

62. Angelidi AM, Belanger MJ, Mantzoros CS. Commentary: COVID-19 and diabetes mellitus: What we know, how our patients should be treated now, and what should happen next. Metabolism. 2020;107:154245.

63. Ghidul pentru persoanele cu diabet în perioada epidemiei de coronavirus. Available at: http://fadr.ro/wp-content/uploads/2016/07/ GHID-diabet-si-coronavirus-2020.pdf (Accessed on 13 May 2020). 